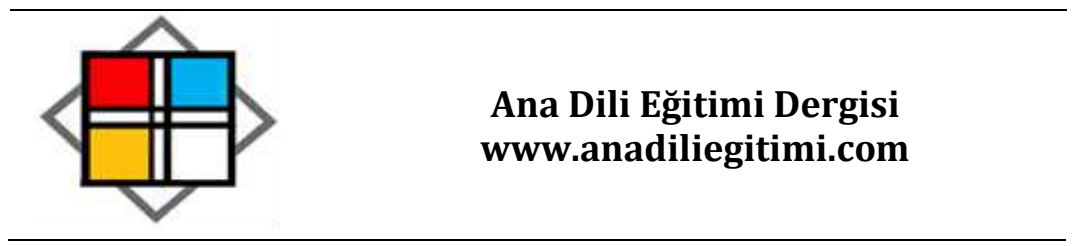

\title{
Türkçe Öğretmen Adaylarının Etkili İletişim Dersine Yönelik Beklentileri
}

\author{
Kemalettin DENIZ*
}

Gönderilme: 22.03.2015 / Düzeltme: 30.03.2015 / Kabul Edilme: 08.04.2015

\section{Öz}

Bu çalışmada Türkçe öğretmeni adaylarının Etkili İletişim dersine yönelik beklenti ve önerileri tespit edilmiş; bu doğrultuda ders içeriğine ve uygulamaya yönelik önerilerde bulunulmuştur. Araştırmanın çalışma grubunu, 2013-2014 ve 2014-2015 eğitim-öğretim yılları bahar yarıyıllarında Gazi Üniversitesi Türkçe Eğitimi Bölümündeki 300 Türkçe öğretmeni adayı oluşturmaktadır. Veriler, öğretmen adaylarının derse yönelik beklenti ve önerilerini yazılı olarak ifade etmeleriyle toplanmış ve doküman analizi yöntemiyle değerlendirilmiştir. Adaylar, dersten beklenti ve derse yönelik önerilerini; 5 boyut, 87 kategori ve 1758 sıklıkta ifade etmişlerdir. Bulguların sınıflandırılmasında öncelikle iletişimin temel ögelerinden yararlanılmıştır. Ardından iletişim engeli, eğitimde iletişim, ders öğretim elemanı ve dersin işlenişine yönelik beklenti ve öneriler verilmiştir. Daha sonra ders içeriği ve beklenti-öneri karşılaştırılması yapılmıştır. Ders içeriği 11 alt konudan oluşmaktadır. İçerikle beklentilerin 5 konuda örtüştüğü, 6 konuda hiçbir beklentinin içeriğe uymadığı ve öğretmen adaylarının içerik haricinde ders öğretim elemanı ve dersin işlenişine yönelik önerilerde bulunduğu tespit edilmiştir. Bu beklenti ve öneriler doğrultusunda ders içeriğinde düzenlemeye gidilmesi ve derse uygulama saatinin eklenmesi uygun olacaktır.

Anahtar kelimeler: Etkili iletişim, öğretmen adayı, Türkçe öğretmenliği, ders içeriği.

\section{Expectations of Turkish Teacher Candidates about the Effective Communication Course}

\begin{abstract}
This study aimed to identify expectations and suggestions of Turkish teacher candidates regarding Effective Communication course and suggestions for the course content and applications were provided accordingly. Working group of the study consisted of 300 Turkish teacher candidates at Gazi University and the study was conducted in the second term of 2013-2014 and 2014-2015 academic years. Data about the expectations and suggestions of Turkish teacher candidates about the course were gathered through written interview protocols in which the participants expressed their opinions in writing and the data were analyzed with the help of document analysis. The teacher candidates expressed their expectations and suggestions about the course in 5 dimensions, 87 categories and with the frequency of 1758. Basic elements of communication were primarily used in the categorization of the findings. Then, expectations and suggestions about communication barriers, communication in education, lecturer and teaching the lesson were given. After that, expectationsuggestion and course content were compared. Course content consists of 11 sub-topics. It was found that content and expectations overlap in 5 topics; no expectation corresponds with the content in 6 topics and teacher candidates made suggestions about the lecturer and the way of conducting the course except for the course content. In light of the expectations and suggestions, it will be appropriate to modify course content and add application time to the course.
\end{abstract}

Keywords: Effective communication, teacher candidate, Turkish language teaching, course content.

\footnotetext{
*Yrd. Doç. Dr., Gazi Üniversitesi, Gazi Eğitim Fakültesi, Türkçe Eğitimi Bölümü. Ankara, Türkiye. e-posta: kemalettindeniz@hotmail.com
} 


\section{Giriş}

Etkili İletişim, 2006-2007 eğitim-öğretim yılından itibaren Türkiye'deki eğitim fakülteleri öğretmen yetiştirme programlarında genel kültür derslerinden biri olarak yer almaktadır.MEB tarafından 2005 yılında yeniden hazırlanan ders programlarıyla ilişkilendirilerek eğitim fakültesi öğretmen yetiştirme programlarında da yeni düzenlemelere gidilmiştir. Bu düzenlemeler, kendisine söyleneni yapan öğretmen yerine, problem çözen ve öğrenmeyi öğreten entelektüel öğretmen yetiştirmeyi hedeflemektedir. Bu amaçla öğretmen yetiştirme programlarına konulan derslerden biri olan Etkili İletişim, programlarda zorunlu ya da seçmeli olarak üç veya iki kredilik teorik ders şeklinde uygulanmaktadır. Dersin adı farklı programlarda çoğunlukla Etkili Iletişim, Etkili Iletişim Becerileri ve Iletişim olarak geçmektedir. Türkçe Eğitimi Programı'nda da Etkili iletişim adıyla üç saatlik teorik bir ders olarak yer almaktadır. Ders içeriği iletişim ve öğretmen-öğrenci iletişimi üzerine yoğunlaşmaktadır. YÖK'ün belirlediği ders içeriğinin öğretmen adayı beklentileriyle örtüşüp örtüşmediği daha fazla verim alınması adına araştırılması gereken konular arasındadır.

Davranış değişikliği meydana getirmek üzere fikir, bilgi, tutum, duygu, haber vb. paylaşılması sürecine iletişim denilmektedir (Köknel, 1997: 35). Bu yönüyle iletişim süreci sınıf içindeki öğretmeöğrenme süreci ile paralellik göstermektedir. Illetişim hayatın her alanında olduğu gibi eğitimde de en önemli etkenlerden biridir ve diğer fonksiyonlarının yanında eğitimin ön koşulunu oluşturarak okulda geçen örgün eğitim sürecinin temelini oluşturmaktadır. Örgün eğitim sürecinde öğrenci, öğretmen ve onun düzenlediği çevre ile etkileşimde bulunur. Öğretme-öğrenme sürecindeki etkinlikler, özünde bir iletişim etkinliği olarak yer almakta, dolayısıyla söz konusu süreç öğretme öğrenme süreci, iletişim süreci ile eşdeğer bir nitelik kazanmaktadır (İmre, 2000: 3). Öğretmen öğrenci etkileşiminin temelinde, öğretmenin kendisinde bulunan bilgi ve becerileri; davranış değiştirme, geliştirme veya oluşturma amaçlarıyla öğrenciyle paylaşması yatmaktadır. Bu paylaşma iletişim yoluyla olmaktadır. Bu anlamda öğrenmenin bir iletişim ürünü olduğu söylenebilir. Eğitime yüklenen başarı-başarısızlık bir anlamda iletişimdeki başarı-başarısızlık olarak kabul edilebilir.

Iletişim ve öğrenme arasındaki ilişki, öğretme-öğrenme süreçlerini iletişim açısından değerlendirmeyi zorunlu kılar. İletişimle ilgili verilerin genelde eğitime, özelde de öğretme-öğrenme sürecine aktarılması gerekmektedir (Özçınar, 2003: 3).

Öğretme ve öğrenme, kaynağı farklı kişilerde olan süreçlerdir. Bu sürece katılan kişilerin kendine özgü nitelikleri vardır. Çok farklı özelliklere sahip olan bu kişiler, eğitim öğretim ortamında bir araya gelir ve sürecin bir parçası olurlar. Öğretme-öğrenme sürecinin başarılı bir şekilde gerçekleşmesi için öğreten ve öğrenenler arasında çok özel bir ilişkinin kurulması gerekir (Gordon, 1998: 3). Yani öğretmen ve öğrenci arasında etkili bir iletişime ihtiyaç duyulur. Burada en büyük pay çoğunlukla kaynak olan öğretmene düşmektedir. Çünkü süreci başlatarak, bu süreçte rehberlik ederek ve aktif rol 
oynayarak öğrenmenin gerçekleşmesini sağlamaya çalışır. Dolayısıyla öğretmenin etkili iletişim becerilerine sahip olması, öğretme-öğrenme sürecinin başarılı şekilde sürdürülmesini sağlar. Her ne kadar okul denince akla ilk gelen okuma ve yazma olsa da okuldaki iletişimin temelinde konuşma ve dinleme yatmaktadır. Öğretmenin konuşma ve dinleme becerilerinde etkili olması, bu becerileri başarılı bir şekilde kullanabilmesi öğretme ve öğrenme ortamının da başarılı olmasının yolunu açmaktadır.

İletişim becerileri konusunda eğitim alan ve almayan öğretmenlerin öğrenciler üzerindeki etkisi üzerine Aspy ve Roebuck (1983) tarafından bir araştırma yapılııştır. Araştırmanın örneklemini altı yüz öğretmen ve anaokulundan lise ikiye kadar değişik sınıflarda okuyan öğrenciler oluşturmaktadır. İletişim becerileri eğitimi almış, öğrencileriyle empati kuran, onları etkili dinleyen öğretmenlerin öğrencilerinde bazı olumlu değişiklikler saptanmıştır: Devamsızlık azalmıştır. Dil ve matematik derslerinde başarı artmıştır. Öğrencilerin düşünme yetenekleri ve yaratıcılıkları gelişmiş, öz saygıları artmıştır. Okul eşyasına zarar verme ve çeşitli disiplin sorunları azalmıştır. Daha çok öğrenci derste söz almaya başlamıştır. Soru soran, öğretmene cevap veren, öğretmenle göz teması kuran ve öğrenmeye istekli öğrencilerin sayısı artmıştır. Araştırmacılar okul yöneticilerinin ve öğretmenlerin çoğunun iletişim becerilerini en alt düzeyde kullandıkları bulgusuna ulaşmışlardır (Akt. Gordon, 2001: 209). Bu araştırmada ortaya çıkan olumlu değişiklikler, her öğretmenin ve eğitim öğretim kademesinin hedefleri arasındadır. Olumlu değişikliklerin ortaya çıkması öğretmenlere iletişim becerilerine yönelik eğitim verilmesi gerekliliğini çok hakıı bir şekilde ortaya koymaktadır.

Teknoloji ve iletişim çağı olarak kabul edilen 21. yüzyılda çok hızlı gelişmeler olmaktadır. Bu gelişmelere paralel olarak istekler ve sunulan hizmetler de artmaktadır. Bireyin topluma ve gelişmelere ayak uydurmasında en önemli görev eğitim sistemine düşmektedir. Eğitim sisteminin lokomotifi ise öğretmenlerdir. Bu yönüyle öğretmenlerin çağın gerektirdiği bilgi ve tecrübeyle donatılmış olması gerekmektedir. Nesil farklııklarının, iletişim çağının ve günümüz kültürünün etkisi altında öğretmen öğrenci iletişiminde problemler ortaya çıkmaktadır. Bu durum, eğitim öğretim faaliyetlerinin kalitesini düşürmektedir. İletişim problemlerinin ortadan kaldırılması, çağımızın gerektirdiği eğitim ve öğretimin verilebilmesi için öğretmenlere önemli sorumluluklar düşmektedir. Bu sorumlulukları yerine getirecek öğretmenlerin yetiştirilmesi ise daha da önemlidir.

Öğretmen yetiştirmede genel kültür, alan bilgisi ve eğitim bilgisi olmak üzere üç temel alan vardır. Bu alanlarla ilgili olarak yeterli düzeyde bilgi ve beceriye sahip olduğu varsayılan öğretmenlerde bir beceri eksik kalmaktadır. Bu da iletişim becerisidir. Eğitim alanına yönelik derslerde öğretmenlere, öğrencilerle iyi iletişim kurmaları gerektiği belirtilmekte ancak bu, daha ayrıntılı ve beceriye dönüşecek bir düzeyde önemsenmemektedir. Öğretmenlerin, amaçlarına kişilerarası iletişim becerilerindeki başarılarıyla doğru orantılı ulaşacakları, öğretmen yetiştiren kurumların göz önünde bulundurmaları gereken bir husustur. Öğretmen adaylarının iletişim becerilerini geliştirmelerine olanak sağlayacak ders 
ve etkinliklere yer verilerek öğretmen adaylarının iletişim konusunda yeterli donanıma sahip biçimde göreve başlamalarını sağlamak mümkündür. (Çuhadar, Özgür, Akgün ve Gündüz, 2014). Öğretmen adaylarının iletişim becerilerinin geliştirilmesi, ikna edici iletişim alanında eğitilmeleri, öğretmen yetiştirme alanlarından biri olarak kabul edilmelidir. Bu amaçla Türkiye'de de önemli adımlar atılmıştır.

Türkiye'de halihazırdaki eğitim fakültesi öğretmen yetiştirme lisans programları, 2006 - 2007 öğretim yılından itibaren uygulanmaktadır. Bu programlar her bir öğretmen yetiştirme alanı için ayrı ayrı oluşturulmuştur. Türkçe Öğretmenliği Lisans Programı da bunlardan biridir. Bu programda Etkili Iletişim 3 kredilik ve 3 saatlik teorik bir ders olarak planlanmıştır. Dersin içeriği şu şekilde belirtilmiştir (YÖK, 2015):

Etkili iletişim (3-0-3)

Kişilerarası iletişimin tanımı, iletişim modeli, iletişim unsurları ve özellikleri, etkili dinleme ve geri bildirim, kişilerarası iletişimi engelleyen etkenler (kaynak, kanal, alıcı vb.), iletişimi kolaylaştıran etkenler, duyguların iletişimde rolü ve kullanılması, iletişimde çatışma ve önlenmesi, öğrenci, öğretmen, veli iletişiminde dikkat edilmesi gereken önemli hususlar, iletişim uygulamaları.

Öğretmen adaylarının etkili iletişimin nasıl kurulması gerektiğine dair bilgiye sahip olmaları yadsınamaz bir gerçektir. Bu bağlamda, öğretmen adaylarının, iletişim becerileri konusundaki bilgi ve görüşlerinin belirlenmesine olanak sağlayacak çalışmalara ihtiyaç bulunmaktadır (Çevik, 2011).

$\mathrm{Bu}$ araştırmanın amacı, Etkili İletişim dersi içeriğinin öğretmen adaylarının derse yönelik beklenti ve önerileriyle örtüşüp örtüşmediğini ortaya koymaktır.

Araştırmadan elde bulgular ders içeriği ve uygulamalarının geliştirilmesi açısından önemlidir.

\section{Yöntem}

\section{Araştırma Modeli}

$\mathrm{Bu}$ araştırmada nitel araştırma yöntemlerinden doküman analizi kullanılmıştır. Doküman analizi, araştırma sonucunda elde edilecek olgu ve kavramlara ulaşmada yol gösterecek olan yazılı malzemenin incelenerek analiz edilmesidir. Doküman incelemesi, araştırılması hedeflenen olay veya olgular hakkında bilgi içeren yazılı materyallerin analizini kapsar (Yıldırım ve Şimşek, 2009).

\section{Veri Toplama}

Araştırmanın çalışma grubunu, 2013-2014 ve 2014-2015 eğitim-öğretim yılları bahar yarıyıllarında Gazi Üniversitesi Türkçe Eğitimi Bölümündeki 300 Türkçe öğretmeni adayı oluşturmaktadır. Adaylara etkili iletişim dersiyle ilgili beklenti ve derse yönelik önerileri sorulmuştur. Veriler, öğretmen adaylarının derse yönelik beklenti ve önerilerini yazılı olarak ifade etmeleriyle toplanmıştır.

\section{Veri Analizi}

Elde edilen verilerin analizinde içerik analizi kullanılmıştır. İçerik analizi, metin veya metinlerden oluşan bir kümenin içindeki belli kelimelerin veya kavramaların varlığını belirlemeye 
yönelik yapılır. Araştırmacı bu kelime ve kavramların varlığını, anlamlarını ve ilişkilerini belirler ve analiz ederek metinlerdeki mesaja ilişkin çıkarımlarda bulunur (Büyüköztürk ve ark. 2008). Araştırmada öğrenci görüşlerini içeren metinlerin analizi işlemi yapılmıştır. Metinlerin incelenmesi aşamasında takip edilen yol şu şekildedir: ilgili metinler araştırmacı tarafından okunmuş, konu ile ilgili olduğu düşünülen ifadeler tespit edilmiş, daha sonra bu ifadeler için bir tema ifadesi yazıımıştır. Aynı işlem başka bir alan uzmanı tarafından da yapılmıştır. İki veri karşılaştırılarak üzerinde uzlaşılan ifadeler tespit edilmiştir. Araştırmada bu ifadeler kategori olarak adlandırılmıştır. Ardından bunlar amaç ve işlevlerine göre boyutlandırılmıştır.

Öğretmen adayı görüşleriyle elde edilen beklenti ve öneri bulguları, etkili iletişim ders içeriğiyle karşılaştırılmıştır. Bu içerik, araştırma bulgularıyla daha rahat kıyaslama amacıyla alt konulara şu şekilde ayrılmıştır:

- Kişilerarası iletişimin tanımı

- Illetişim modeli

- Illetişim unsurları ve özellikleri (kaynak, kanal, alıcı vb.)

- Etkili dinleme

- Geri bildirim

- Kişilerarası iletişimi engelleyen etkenler

- İletişimi kolaylaştıran etkenler

- Duyguların iletişimde rolü ve kullanılması

- Illetişimde çatışma ve önlenmesi

- Öğrenci, öğretmen, veli iletişiminde dikkat edilmesi gereken önemli hususlar

- Iletişim uygulamaları.

\section{Bulgu ve Yorumlar}

Bulguların sınıflandırılmasında iletişimin temel ögeleri olan kaynak, mesaj, kodlama, kanal, alıcı ve geri bildirimden öncelikli olarak yararlanılmıştır. Daha sonra iletişim engeli, eğitimde iletişim, ders öğretim elemanı ve dersin işlenişine yönelik beklenti ve öneriler verilmiştir. Öğretmen adayları toplam 5 boyut, 87 kategori ve 1758 sıklıkla beklenti ve önerilerini ifade etmişlerdir.

\section{iletişim Unsurları}

Temel İletişim unsurları kaynak, mesaj, kodlama, kanal, alıcı ve geri bildirimdir.

\section{Kaynak}

Kaynak, iletişimi başlatan ve iletilmek isteneni alıcıya gönderendir. Kişilerarası iletişimde bu, insan veya insanlardan oluşan bir gruptur. Kaynak; iletişimi başlatma, mesaj oluşturma ve bu mesajı alıcıya göre düzenleme, iletmek istediğini uygun bir kanalla alıcıya ulaştırma, geri bildirim alma 
aşamalarında aktif rol aldığı için iletişim sürecinin en önemli ögesidir. Kaynağın bu alanlardaki becerisi iletişimin etkililiğini artırmaktadır. Mesaj iletimi yoluyla karşısındakini veya karşısındakileri etkileme amacı güden kaynak; düşünce, inanç tutum ve davranış değiştirebilir. Kaynağın inandırıcı olabilmesi için birtakım özelliklere sahip olması gerekir (Deniz, 2013: 522).

\section{Tablo 1: Kaynağa Yönelik Beklentiler ve Sıklığı}

\begin{tabular}{|c|c|c|}
\hline Alt Boyut & Beklentiler & Sıklık \\
\hline 1.1 & İnsanlarla etkili iletişim kurabilmek & 151 \\
\hline 1.2 & Kendini doğru ve en iyi şekilde ifade edebilmek & 138 \\
\hline 1.3 & Topluluk önünde konuşabilme (hitabet) yeteneğini geliştirmek & 83 \\
\hline 1.4 & İkna yeteneğini geliştirmek & 53 \\
\hline 1.5 & Güzel ve etkili konuşmak* $^{*}$ & 45 \\
\hline 1.6 & Doğru şekilde iletişime geçebilmek & 16 \\
\hline 1.7 & Bir sunucu kadar başarılı olmak & 2 \\
\hline 2.1 & Hitap edilen gruba hâkim olabilme becerisi kazanmak & 24 \\
\hline 2.2 & Topluma ve öğrencilere örnek olabilmek & 23 \\
\hline 2.3 & İnsanları etkileyebilmek, saygınlık kazanmak ve lider olmak & 21 \\
\hline 2.4 & İyi bir dinleyici olmak & 15 \\
\hline 2.5 & Güven duygusu aşılayabilmek & 11 \\
\hline 2.6 & Aile içinde söz sahibi olmak & 1 \\
\hline 3.1 & Özgüven kazanmak & 33 \\
\hline 3.2 & Sorunlara etkili çözüm bulma becerisi kazanmak & 25 \\
\hline 3.3 & Daha etkin bir birey olmak & 22 \\
\hline 3.4 & Donanımlı ve bilgili olmak & 9 \\
\hline 3.5 & Girişimcilik becerisini artırmak & 5 \\
\hline 3.6 & Çekingenliği yenmek & 3 \\
\hline 4.1 & Zamanı, mekanı ve imkanları etkili kullanabilmek & 9 \\
\hline 4.2 & Hayatımı kolaylaştırmak & 7 \\
\hline 4.3 & Sosyal aktivitelere katılabilmek & 6 \\
\hline 5.1 & Kendimi anlamak & 9 \\
\hline 5.2 & Fevri hareketleri iletişimle frenleyebilmek & 2 \\
\hline 5.3 & Psikolojik rahatsızlıklarımı düzeltmek & 2 \\
\hline 5.4 & Olumlu bakış açısı kazanmak & 2 \\
\hline 5.5 & NLP’nin tüm yönlerini öğrenmek & 1 \\
\hline 6.1 & İlginç bilgiler öğrenmek & 1 \\
\hline 6.2 & Nerede nasıl giyinileceğini öğrenmek & 1 \\
\hline 6.2 & İsim hafızamı güçlendirmek & 1 \\
\hline 6.3 & Dikkat becerimi geliştirmek & 1 \\
\hline Toplam & 31 & 722 \\
\hline
\end{tabular}

Veri toplanan grup öğretmen adayları olduğu için çoğunlukla kendilerini kaynak yerine koyarak yani iletişimi başlatan kişi olarak görmüşlerdir. Bu sebeple çalışmada ortaya çıkan öneri ve beklentilerin

\footnotetext{
* Güzel ve etkili konuşmak (45) kategorisi hem kaynak hem kanal; topluma ve öğrencilere örnek olabilmek (23) kategorisi ise hem kaynak hem de eğitimde iletişim boyutlarında ortak kullanılmıştır. Çünkü iki boyutun da içeriğinde ele alınabilecek niteliktedir.
} 
çoğu da kaynağa yöneliktir. Tablo 1'de beklentiler ön plandadır. 31 farklı beklenti 722 sıklıkla dile getirilmiştir. Beklentileri kendi içinde alt boyutlara ayırmak mümkündür.

Tablodaki birinci boyutu oluşturan ilk altı beklentide katılımcılar genelde başarılı ve etkili bir iletişim kurma isteklerini ortaya koymuşlardır. Bu, 488 sıklıkla beklenen bir sonuçtur. Çünkü dersin adı, çağrışımları ve genel amacı buna yöneliktir. Burada dikkat çeken hususlardan biri ikna yeteneği ifadesinin kullanılmasıdır. Çünkü ikna, etkili iletişimin olumlu yönünü ifade etmektedir. Bunun ayırdına varılarak kullanılıp kullanılmadığı ise tespit edilememiştir. Bir başka husus ise adayların bir sunucu kadar başarılı olmak ifadesiyle benzetme yoluyla etkili iletişim kurma isteklerini dile getirmeleridir.

Kaynakla ilgili ikinci alt boyutta ise katılımcılar beklentilerini alıcı üzerinden dile getirmişlerdir. 6 kategoride toplam 95 sıklıkla ifade edilen beklentiler, hitap edilen gruba hâkim olabilme, onlara örnek olma, iyi bir dinleyici olma, güven duygusu ve saygınlık yoluyla lider olma ve aile içinde söz sahibi olma amaçlarını taşımaktadır. Öğretmen öğrenci iletişimi açısından değerlendirildiğinde etkili iletişim yoluyla lider öğretmen tipi beklentisinin öne çıktığı görülmektedir.

Inandırıcılık temelde alanında uzman olma ve güvenilirlikle ilgilidir (Kağıtçıbaşı, 2005; Muallimoğlu, 2005). Alıcı veya alıcıların kaynağa güvenmesi, alanında uzman olmanın sağladığı itibar ve inanç, etkilemede önemli etkenlerdir. Karadoğan (2003), kişilerarası iletişimde güven ve ikna konulu araştırmasında, bir kişinin ikna edebilir olması için başta güvenilir olması ve yalan söylememesi sonucuna ulaşmıştır (Akt. Deniz, 2007: 24).

Öğretmen adaylarının kaynak olarak yukarıda belirtilen beklentileri daha çok karşı taraf üzerinde etkili olmayla ilgiliyken kendi kişisel gelişimleri üzerine beklentileri de mevcuttur. Bu üçüncü alt boyut, 6 kategoride 97 sıklıkla ifade edilmiştir. Beklentiler; özgüven sahibi, girişimci, çekingenliği yenmiş, donanımlı-bilgili, sorunlara etkili çözümler bulan etkin bir birey olma şeklinde ortaya konmuştur. Karadoğan'ın (2003) araştırmasında da güvenilirliği ve etkilemeyi sağlayan unsurlar arasında kendine güvenme, açık sözlü, birikimli ve uyumlu olma özellikleri vardır.

Dördüncü alt boyutta öğretmen adayları etkili iletişim dersiyle zamanı-mekânı ve imkanları etkili kullanabilme, sosyal aktivitelere katılabilme ve hayatlarını kolaylaştırma beklentilerini 3 kategoride 22 sıklıkla dile getirmişlerdir. Zamanı ve mekânı etkilemede bir araç olarak kullanma, etkileme teknikleri arasındadır (Hale ve Whitlam, 1997; Rocha 2003; Akt. Karadoğon, 2003).

Beşinci alt boyutta öğretmen adayları bu dersten beklentilerini kendi psikolojik durumları üzerinde yoğunlaştırmışlardır: Kendini anlamak, fevri hareketleri iletişimle durdurabilmek, psikolojik rahatsızlıklarından kurtulmak, olumlu bakış açısı kazanmak ve NLP'yi öğrenmek. 16 sıklıkla ifade bulan bu alt boyut iletişim açısından önemli olsa da öğretmen adayı beklentilerinde yeterince kendine yer bulamamıştır.

Anlatabilmek ve etkileyebilmek için bireyin kendi duygu ve düşünce dünyasını iyi tanıması ve kendini ifade edebilmesi gereklidir (Uzuntaş 2013). Cialdini, Türkçeye iknanın Psikolojisi (2006) ve 
Insanları Etkileme Yolları (2001) adlarıyla çevrilen eserinde, insan davranışını yönlendiren temel psikolojik ilkeleri yani uyma psikolojisini sağlayan ikna tekniklerini ortaya çıkarmaya çalışmıştır. Bu açıdan bakıldığında adayların psikolojik durumlarla ilgili beklenti içinde olmaları doğaldır.

Etkili iletişim açısından önemli, hatta teknik olarak da literatürdeki (Hogan 2007; Hogan ve Speakman, 2007) yerini almış bazı beklentiler ise maalesef öğretmen adayları tarafından yeterince önemsenmemiştir. Bunlar: Illginç bilgiler öğrenmek, nerede nasıl giyinileceğini bilmek (dış görünüş), isim hafızasını güçlendirmek, dikkat becerisini geliştirmek. Bu alt boyuttaki dört beklenti birer kez ifade edilmiştir.

Mesaj

İletişimin temel ögelerinden biri mesajdır. Mesajın tespit edilmesi ve düzenlenmesi sürecinde zihinsel beceriler önemlidir.

Tablo 2: Mesaja Yönelik Beklentiler ve Sıklığı

\begin{tabular}{|l|l|c|}
\hline & \multicolumn{1}{|c|}{ Beklentiler } & Sıklık \\
\hline 1 & Mesaj düzenleme & 11 \\
\hline 2 & Bakış açısını genişletmek & 10 \\
\hline 3 & Objektif olmak & 5 \\
\hline 4 & Yaratıcılığı geliştirmek & 2 \\
\hline 5 & Düzenli ve planlı konuşabilmek (zihni düzenlemek) & 1 \\
\hline Toplam & 5 & 29 \\
\hline
\end{tabular}

Öğretmen adayları Etkili İletişim dersi yoluyla mesaja yönelik bazı beklentilerini 5 kategoride 29 sıklıkla ifade etmişlerdir. Bakış açısını genişletmek, objektif olmak, yaratıcılı̆̆ı geliştirmek, düzenli ve planlı konuşabilmek (zihni düzenlemek). Sıklık ve kategori sayısının az olmasına rağmen onların böyle bir beklenti içinde olmaları kayda değer önem arz etmektedir.

Mesajın oluşturulması ve ifade edilmesinin yanı sıra mesajın içeriğinde konunun hem lehinde hem de aleyhinde bilgi içermesi gibi özellikler de etkili iletişim açısından önemlidir (Cüceloğlu, 1993: 522). Yukarıdaki bulgularda katılımcıların zihinsel becerilerini geliştirme beklentileri içinde olmaları etkili iletişim açısında olumlu bir göstergedir.

Kodlama

Illetişimin etkili hâle gelmesinde mesajın yansıtıldığı ortak simge (dil, beden dili, görsel vb.) en etkili unsurlardan biri olarak kabul edilmektedir. Kod, aktarılma durumunda kaynağın zihnindeki mesajın yerine geçen, onu temsil eden somut bir biçimdir. Bilgi, duygu, düşüce, istek vb.lerin bir sistem dâhilinde sembollerle iletime uygun mesaj hâline getirilmesine kodlama denir (Tutar ve Yılmaz, 2003: 25). 
Tablo 3: Kodlamaya Yönelik Beklentiler ve Sıklığı

\begin{tabular}{|l|l|c|}
\hline Alt Boyut & \multicolumn{1}{|c|}{ Beklentiler } & Sıklık \\
\hline 1 & Dil & 138 \\
\hline 1.1 & Kendini doğru ve en iyi şekilde ifade edebilmek & 31 \\
\hline 1.2 & Dili etkili şekilde kullanabilmek & 19 \\
\hline 1.3 & Anlaşılır bir dil kullanmak & 3 \\
\hline 1.4 & Kelime hazinemi geliştirmek & \\
\hline & & 88 \\
\hline 2 & Beden Dili & 23 \\
\hline 2.1 & Beden dilini etkili kullanabilmek ve anlayabilmek & 3 \\
\hline 2.2 & Öğrenci karşısında etkili bir duruşa sahip olmak & 1 \\
\hline 2.3 & Göz teması kurabilmek & \\
\hline 2.4 & Güler yüzlü olabilmek & 1 \\
\hline \multicolumn{1}{|c|}{9} & 307 \\
\hline 3 & Okuma & \\
\hline 3.1 & Okuma alışkanlığı kazanmak & \\
\hline Toplam & & \\
\hline
\end{tabular}

Türkçe öğretmeni adayları dil becerilerinin geliştirilme boyutunu dört kategoride 191 sıklıkla belirtmişlerdir. Bunlardan kendini doğru ve en iyi şekilde ifade edebilmek 138 sıklıkla mesajın etkili bir şekilde alıcıya iletilmesi isteğini yansıtmaktadır. Diğer bir yaygın kodlama şekli olan beden dilinin geliştirilmesine yönelik beklenti sıklığı $115^{\prime}$ tir. Genelde beden dili ve özelde etkili duruş, göz teması ve güler yüz alt kategorilerdir. Sözsüz Iletişim Kuran birey tipi (Norton, 1983) beden dilini ve sözsüz iletişim kodlarını kullanan, iletişim esnasında göz teması ile jest ve mimiklerini etkili bir biçimde kullanıp karşı tarafı etkileyen kişilerdir (Akt. Çuhadar ve ark. 2014). Öğretmen adaylarının da bu birey tipine uygun bir beklenti içinde oldukları görülmektedir.

Okuma alışkanlığının geliştirilmesini bir aday beklemektedir. Bu beklenti, kodlamada temel unsur olan kelime hazinesinin ve dil becerilerinin geliştirilmesi açısından önemlidir.

Iletişim kurma ihtiyacı insanları ortak kodlama sistemleri oluşturmaya götürmüştür. Bunların başında dil gelmektedir. Dil, insanlar arası iletişimin en yaygın mesaj kodlayıcı sistemidir. Kişilerin, toplumların nesilden nesle aktararak ve geliştirerek getirdikleri üzerinde uzlaşılmış kelime, bağlayıcı ve cümle yapıları, onları kullanan insanların ortak dillerini oluşturmaktadır. Kodlama sadece dille değil üzerinde kişilerce bilinçli veya bilinçsiz bir şekilde uzlaşıya varılmış birçok sembolle de yapılmaktadır. Mesaj; dil, beden (bedenin genel duruşu, el-kol ve bacakların hareketi, yüz ifadeleri, göz), görsel (fotoğraf, resim, grafik, renk vb.) ses, rakam, nota gibi sistemlerle kodlanabilir (Deniz, 2015: 457).

Kodlama sistemlerinin geliştirilmesine yönelik sıklık (307), genele bakıldığında yüksek gibi gözükse de mesajın alıcıya aktarılmasındaki işlevi sebebiyle daha ayrıntılı ve daha fazla talep gelmesi beklenen bir durum olurdu. Bu alt boyutta 21. yüzyıl insanının hayatın her alanında kullandığı görsel kodlamayla ilgili bir talebin olmaması ise önemli bir eksiklik olarak algılanmalıdır. 


\section{Kemalettin DENiz}

Kanal

Kanal, iletilen mesajı kaynaktan alıcıya ulaştıran yoldur (Evliyaoğlu, 1987: 134). Yazılı, sözlü, bedensel ve görsel kanallar en yaygın kullanılan türüdür. Bu kanalların taşındığı ortamlar da iletişim araçlarıdır. Kişilerarası iletişimde en sık yazılı ve sözlü kanal kullanılır.

Tablo 4: Kanala Yönelik Beklentiler ve Sıklığı

\begin{tabular}{|l|l|c|}
\hline Alt Boyut & \multicolumn{1}{|c|}{ Beklentiler } & Sıklık \\
\hline 1 & Konuşma & \\
\hline 1.1 & Güzel ve etkili konuşmak & 45 \\
\hline 1.2 & Heyecanı yenebilmek & 17 \\
\hline 1.3 & Kişilerarasında konuşabilecek ortak noktalar bulabilmek & 3 \\
\hline 1.4 & Doğaçlama konuşabilmek & 1 \\
\hline & & \\
\hline 2 & Diksiyon & 46 \\
\hline 2.1 & Kelimeleri doğru telaffuz edebilmek ve diksiyonun düzgün olması & 14 \\
\hline 2.2 & Ses tonunu ayarlayabilme ve doğru vurgu kullanma & 5 \\
\hline 2.3 & Ağız özelliklerinden kurtulmak & 3 \\
\hline 2.4 & Diyafram nefesi almayı öğrenmek & \\
\hline & & 3 \\
\hline 3 & Yazma & 137 \\
\hline 3.1 & Etkili yazmak & 9 \\
\hline Toplam & & \\
\hline
\end{tabular}

Öğretmen adayları kanalla ilgili beklentilerini yazmada bir olmak üzere toplam 9 kategoride 137 sıklıkla ifade etmişlerdir. Araştırmanın bu boyutunda konuşma kanalıyla ilgili adayların doğrudan konuşma olarak belirttikleri, konuşmanın fiziki yönüne değinen ve bir kodlama biçimi olarak sese yönelik bulgulara yer verilmektedir. Güzel ve etkili konuşma, ortak noktaları bulabilme ve doğaçlama konuşabilme kategorilerinde, ağırlık birincisinde olmak üzere, 49 sıklıkta beklentiler açıklanmıştır. Konuşmanın zihinsel ve fiziki unsurlarından heyecanı yenebilmek 17 sıklıkla talep bulmuştur. Adaylar doğru telaffuz, diksiyon, ses tonunu ayarlayabilme, doğru vurgu, ağız özelliklerinden kurtulma ve diyafram nefesi alma beklentilerini 68 sıklıkla ifade etmişlerdir. Türkçe Eğitimi Bölümü Lisans Programı'nda yer alan sözlü anlatım (iki dönem), ses eğitimi(seçmeli) gibi dersler öğretmen adaylarının bu beklentilerini yerine getirecek içeriğe sahiptir. Buna rağmen hâlen beklentilerin devam etmesi düşündürücü bir durumdur.

20. yüzyılla birlikte sıkça kullanılan yazma kanalına ilişkin, etkili yazmak şeklinde sadece bir kategoride üç sıklıkla talep gelmiştir. Bu da adayların etkili iletişimi daha çok sözel olarak gördüklerini ortaya koymaktadır.

AlıcI

Illetişimin asıl amacı alıcıda tutum ve davranış değişikliği oluşturmaktır. Bu yönüyle alıcı iletişimde pasif gibi gözükse de alıcıyı anlamak ve onların özelliklerini bilmek bilhassa etkili iletişim teknikleri açısından önemlidir. 
Tablo 5: Alıcıya Yönelik Beklentiler ve Sıklığı

\begin{tabular}{|l|l|c|}
\hline & \multicolumn{1}{|c|}{ Beklentiler } & Sıklık \\
\hline 1 & Hitap edilen grubun psikolojisini anlamak & 81 \\
\hline 2 & Empati kurmak (karşısındakini anlayabilmek) & 65 \\
\hline 3 & Hitap edilen gruba uygun konuşmak & 21 \\
\hline Toplam & 3 & 167 \\
\hline
\end{tabular}

Öğretmen adayları Etkili İletişim dersinde alıcıyla ilgili, hitap edilen grubun psikolojisini anlamak, empati kurmak (karşısındakini anlayabilmek), hitap edilen gruba uygun konuşmak kategorilerinde 167 sıklıkla beklentilerini dile getirmişlerdir. Özellikle empati kurmanın etkili bir iletişimin temeli olduğu, sınıf ortamında da empatik ilişkilerin farklı ve özel bir iletişim yaratarak öğrencilerin öğrenme düzeylerinde artış sağladığı, buna karşın saldırgan davranışların azaldığı bilinmektedir (Güven ve Yalçınkaya Akyüz, 2001). Bu açıdan adayların empati kurmaya yönelik beklentileri olumlu bir durumdur.

\section{Geri Bildirim}

Öğretmen adayları geri bildirim alma becerilerini geliştirme yönünde beklenti ifade etmemişlerdir. Buna rağmen bulgular arasında geri bildirime yönelik bir bölüme yer verilmesi, iletişim döngüsündeki önemine dikkat çekmek içindir. Geri bildirim kaynağın mesaj vermek istediği alıcının mesajı alıp almadığı, almışsa tepkisinin ne olduğu hakkında bilgi temin ettiği süreci ifade etmektedir. Böyle bir bilgi, devam eden ve devam edecek olan iletişim davranışını gözden geçirme veya değiştirmeye yardım edebilir. Yüz yüze iletişimde geri bildirim almak isteyen bireyler bunu, soru sorma, mesajın tekrar edilmesini isteme, jest ve mimiklerden yararlanma vb. şekillerde gerçekleştirebilirler (Mcquail ve Windahl, 1993: 6). Türkiye'de 2006 yılından beri öğrenci merkezli bir sisteme geçilmiştir. Öğretmen-öğrenci etkileşiminin daha yoğun beklendiği bu sistemde öğretmen adaylarının geri bildirime yönelik talepte bulunmamaları araştırmanın ilginç bulgularından biridir.

Araştırmaya katılan adaylar, etkili iletişim dersinde iletişimin temel ögeleriyle ilgili beklentilerini ifade etmelerinin yanı sıra farklı boyutlardaki konulara yönelik beklentilerini de aktarmışlardır. Bunlardan biri de iletişim engeli konusudur.

\section{İletişim Engeli}

Tablo 6: Iletişim Engeline Yönelik Beklentiler ve Sıklı̆ıı

\begin{tabular}{|l|c|c|}
\hline & Beklentiler & Sıklık \\
\hline 1 & İletişimdeki aksaklıkları düzeltebilmek & 12 \\
\hline 2 & İletişim kaynaklı sorunlar yaşamamak & 12 \\
\hline Toplam & 2 & 24 \\
\hline
\end{tabular}

Katılımcılar iletişimdeki aksaklıkları düzeltebilmek ve iletişim kaynaklı sorunlar yaşamamak kategorilerinde 24 sıklıkla etkili iletişimden ziyade sağlıklı iletişim kurmaya yönelik beklenti içinde olduklarını belirtmişlerdir. Iletişim ortamlarında pek çok nedenden dolayı çatışma ve iletişim engeli ortaya çıkabilir. Özellikle kişilerin farklı özelliklere ve bakış açılarına sahip olması durumunda 
çatışmaların ve dolayısıyla engellerin ortaya çıkması kaçınılmazdır (Gürüz ve Temel Eğinli, 2013: 222). Katılımcıların iletişim engellerini ortadan kaldırmaya yönelik beklentileri iletişim açısından olumlu bir durumdur.

\section{Eğitimde İletişim}

Eğitimde iletişim kavramı araştırmanın problem durumu ortaya konulurken betimlenmiştir. Temel unsurlarını öğretmen, öğrenci, meslektaş, yönetici, veli ve diğer kişiler oluşturmaktadır.

Tablo 7: Eğitimde Illetişime Yönelik Beklentiler ve Sıklığı

\begin{tabular}{|l|l|c|}
\hline & \multicolumn{1}{|c|}{ Beklentiler } & Sıklık \\
\hline 1 & Öğrencilerle etkili iletişim kurabilmek & 131 \\
\hline 2 & Etkili şekilde ders anlatabilmek & 87 \\
\hline 3 & Yöneticilerle meslektaşlarla ve velilerle sağlıklı iletişim kurabilmek & 29 \\
\hline 4 & Öğrenci karşısında etkili bir duruşa sahip olmak & 23 \\
\hline 5 & Topluma ve öğrencilere örnek olabilmek & 23 \\
\hline 6 & Eğlenceli şekilde ders anlatabilmek & 10 \\
\hline 7 & Dersi günlük olaylarla ilişkili anlatma becerisi kazanmak & 6 \\
\hline 8 & Derslerde motivasyon artışı sağlayabilmek & 2 \\
\hline 9 & Öğrencilerin eksiklerini tespit edebilmek & 1 \\
\hline 10 & Güzel ve etkileyici etkinlikler hazırlamak (şiir dinletisi, tiyatro, sunum) & 1 \\
\hline Toplam & \multicolumn{1}{c}{10} & 313 \\
\hline
\end{tabular}

Katılımcılar öğretmen adayı oldukları için gelecekteki mesleklerinde sıkça iletişim içinde olacakları başta öğrenciler olmak üzere meslektaşları ve yöneticilerle etkili iletişim kurmaya yönelik beklentilerini belirtmişlerdir. Tablo 7'de toplamda 10 kategoriyle 313 sıklıkta ifade edilen beklentiler kendi içinde sınıflandırılabilir. Bunların başında, öğrenci, yönetici, meslektaş ve velilerle etkili iletişim kurabilmek gelmektedir. Etkili ve eğlenceli şekilde ders anlatabilmek, dersi günlük olaylarla ilişkilendirebilme becerisi kazanmak ve derslerde güzel-etkileyici etkinlikler hazırlamak 104 sıklıkla beklentiler içindeki önemli payı almaktadır. Öğrenci karşısında etkili bir duruşa sahip olmak, öğrencilere-topluma örnek olmak ve derslerde motivasyon artışı sağlayabilmek 48 sıklıkla ifade edilen beklentilerdir. 10 kategoriden biri olan öğrencilerin eksiklerini tespit edebilmeye yönelik ise bir talep gelmiştir. Aslında bu teknik öğrenci ihtiyaçlarını bilme ve mesajları buna göre düzenleme açısından önemli bir durumdur. Tamamına bakıldığında bu boyuttaki kategoriler etkili iletişim sağlamaya yönelik değil daha çok etkili iletişimin kullanım alanları üzerinedir.

\section{Ders Öğretim Elemanı}

Bundan önceki boyutlarda öğretmen adaylarının etkili iletişim dersine yönelik beklentileri ifade edilmiştir. Son iki boyutta ise dersin öğretim elemanı ve dersin işlenme şekliyle ilgili beklenti ve önerilerine yönelik bulgular ortaya konmaktadır. 
Tablo 8: Ders Öğretim Elemanına Yönelik Öneriler ve Sıklığı

\begin{tabular}{|l|l|c|}
\hline & \multicolumn{1}{|c|}{ Öneriler } & Sıklık \\
\hline 1 & Tecrübelerinden hareketle ders işlemeli & 3 \\
\hline 2 & Günlük hayattan örnekler vermeli & 3 \\
\hline 3 & Bilgili ve donanımlı olmalı & 2 \\
\hline 4 & Derste anlatılanlar anlaşılır olmalı & 1 \\
\hline Toplam & 4 & 9 \\
\hline
\end{tabular}

Ders öğretim elemanıyla ilgili bilgili ve donanımlı olması, tecrübelerinden yararlanması, günlük hayattan örnekler yansıtması ve anlaşılır bir dille ders işlemesi kategorilerinde 9 sıklıkla beklenti-öneri dile getirilmiştir. Bu boyuta yönelik bir önerinin oluşması, adayların daha önceki derslerde ders içeriği ile uyuşmayan şekilde ders işleyen öğretim elamanlarının varlığına işaret edebilir.

\section{Dersin İşlenişi}

Katılımcılar, etkili iletişim dersinin işlenişine yönelik öneri ve beklentiler de sunmuşlardır.

Tablo 9: Dersin İslenişine Yönelik Öneriler ve Sıklığı

\begin{tabular}{|l|l|c|}
\hline & \multicolumn{1}{|c|}{ Öneriler } & Sıklık \\
\hline 1 & Ders uygulamalı olmalı & 39 \\
\hline 2 & Uygulanabilir bilgiler verilmeli & 25 \\
\hline 3 & Kitap, ek kaynak, makale vb. okutulmalı & 13 \\
\hline 4 & Sözlü anlatım dersinin devamı olmalı & 11 \\
\hline 5 & Ders eğlenirken öğretmeli & 5 \\
\hline 6 & Değerlendirme uygulamalı olmalı & 5 \\
\hline 7 & Yetenekler açığa çıkarılmalı & 3 \\
\hline 8 & Sınıftaki pasif öğrenciler de iletişime geçirilmeli & 3 \\
\hline 9 & Kısa filmlerle ders işlenmeli & 3 \\
\hline 10 & Derste öğrenilenler günlük hayata aktırılabilmeli & 3 \\
\hline 11 & Bu derse daha fazla zaman ayrılmalı & 2 \\
\hline 12 & Şiir okuma ve ezberletme uygulaması yapılmalı & 2 \\
\hline 13 & Konuyla ilgili seminer duyurulmalı & 1 \\
\hline 14 & Ders etkileşim içinde işlenmeli & 1 \\
\hline 15 & Ders öğrenci üzerine kurulmamalı & 1 \\
\hline 16 & Ders drama tekniğiyle işlenmeli & 1 \\
\hline Toplam & & 118 \\
\hline
\end{tabular}

Tablo 9'daki verilere bakıldığında adaylar 16 kategoride toplam 118 sıklıkla beklenti-öneri belirtilmiştir. Bunların yoğunlaştığı kategoriler şunlardır: Ders uygulamalı olmalı, sözlü anlatım dersinin devamı olmalı, eğlenirken öğretmeli; derste kitap, ek kaynak, makale vb. okutulmalı, kısa filmlerden yararlanılmalı, uygulanabilir bilgiler verilmeli ve dersin değerlendirmesi uygulamalı yapılmalı. Bir veya birkaç adayın beklenti ve önerileri ise şöyledir: Derste yetenekler açığa çıkarılmalı, sınıftaki pasif öğrencilerle iletişime geçilmeli, şiir okuma ve ezberletme uygulaması yapılmalı, drama tekniğinden yararlanılmalı, konuyla ilgili seminerler duyurulmalı; ders öğrenci üzerine kurulmamalı, etkileşim içinde işlenmeli; derse daha fazla zaman ayrılmalı.

Ders içeriğinden ziyade dersin işlenme şekline yönelik bu beklentiler, dersin kalitesini artırmaya yöneliktir. Derste uygulamaya yönelik beklentiler, üç kredilik teorik bir ders olarak tasarlanan Etkili İletişim'in uygulamalı bir ders şeklinde planlanması gereğine ipucu oluşturmaktadır. Yarar Kaptan ve Oğuz 
(2011) araştırmasında, Etkili Illetişim dersinin öğretmen adaylarının iletişim becerileri üzerinde istatistiksel olarak herhangi bir farklılığa yol açmamasının bir sebebini, dersin teori ağırlıklı olup ders saatinin beceri geliştirmeye dönük etkinliklerin yapılması için yetersiz oluşu olarak belirtmektedir. Uzuntaş (2013) etkili iletişim derslerinde uygulamaya yönelik etkinlik materyallerinin eksikliğinden yakınarak bu konuda örnek bir çalışma ortaya koymuştur.

Yukarıda aktarılan bulgular, öğretmen adaylarının Etkili illetişim dersine yönelik beklenti ve önerilerini yansıtmaktadır. Araştırmanın asıl amacı YÖK tarafından oluşturulan ders içeriğinin öğretmen adaylarının derse yönelik beklenti ve önerileriyle örtüşüp örtüşmediğini ortaya koymaktı. Bu amaç doğrultusunda karşılaştırmayı içeren bulgular şu şekildedir:

\section{Ders İçeriği ve Beklenti-Öneri Karşılaştırılması}

Tablo 10: Ders İçeriği ve Beklenti-Öneri Karşılaştırılması

\begin{tabular}{|c|c|c|c|}
\hline \multicolumn{2}{|r|}{ Ders İçeriği } & \multicolumn{2}{|c|}{ Beklenti / Öneri (Kategori-Sıklık Sayısı) } \\
\hline 1 & Kişilerarası iletişimin tanımı & \multicolumn{2}{|c|}{-} \\
\hline 2 & İletişim modeli & \multicolumn{2}{|r|}{-} \\
\hline 3 & $\begin{array}{l}\text { İletişim unsurları ve özellikleri (kaynak, kanal, alıcı } \\
\text { vb.) }\end{array}$ & $\begin{array}{l}\text { Kaynak : } \\
\text { Mesaj : } \\
\text { Kodlama: } \\
\text { Kanal : } \\
\text { Alıcl : } \\
\text { Toplam : }\end{array}$ & $\begin{array}{l}31-722 \\
5-29 \\
9-307 \\
9-137 \\
3-167 \\
57-1362\end{array}$ \\
\hline 4 & Geri bildirim & & - \\
\hline 5 & Etkili dinleme $^{+}$ & & $1-15$ \\
\hline 6 & Kişilerarası iletişimi engelleyen etkenler & & $2-24$ \\
\hline 7 & illetişimi kolaylaştıran etkenler & & - \\
\hline 8 & Duyguların iletişimde rolü ve kullanılması & & - \\
\hline 9 & İletişimde çatışma ve önlenmesi & & - \\
\hline 10 & $\begin{array}{l}\text { Öğrenci, öğretmen, veli iletişiminde dikkat } \\
\text { edilmesi gereken önemli hususlar }\end{array}$ & & $10-313$ \\
\hline 11 & İletişim uygulamaları & & $3-45$ \\
\hline Toplam & 11 & & $73-1759$ \\
\hline
\end{tabular}

Ders içeriği 11 alt konudan oluşmaktadır. Öğrenci beklenti ve önerileri de 5 boyutta toplanmıştır. Bu konular esas alınarak bir kıyaslama yapılımıştır. Kıyaslamada temel alınan husus ders içeriğidir.

Birinci konu kişilerarası iletişimin tanımıdır. Bu konuyla ilgili bir beklenti mevcut değildir. Öğretmen adaylarııın bir tanım beklentisi içinde olmamaları doğal kabul edilebilir. Temelde beklentiler kişilerarası iletişim konusuyla ilgilidir. Ancak kişilerarası iletişim kavramıyla ilgili hiçbir beklenti ortaya koymamaları ders içeriği ile bu konuda örtüşmediklerini ifade etmektedir.

Ders içeriğinin ikinci konusu iletişim modelleridir. Öğretmen adaylarının bu konuda da bir beklentileri mevcut değildir. İletişim modelleri dersin teorik ve kuramsal konularından biridir. Öğrenci beklentileri daha çok uygulamaya yoğunlaşmıştır.

\footnotetext{
${ }^{+}$Bu kategori kaynağın bir özelliği olduğu için orada da değerlendirilmeye alınmıştır.
} 
İ̧̧eriğin üçüncü konusu iletişim unsurları ve özellikleridir. Iletişimin temel ögeleri; kaynak, mesaj, kodlama, kanal, alıcı ve geri bildirimdir. Öğretmen adaylarının beklenti ve önerilerinin büyük çoğunluğu bu unsurlara yöneliktir. Katılımcılar iletişim unsurlarına yönelik beklentilerini toplamda 56 kategoride 1362 sıklıkla dile getirmişlerdir. Bunlarda en büyük payı 722 sıklıkla kaynak almaktadır. Mesaja yönelik 29, kodlamaya 307, kanala 137 ve alıcıya 167 sıklıkla beklenti ifade edilmiştir. İletişim ögelerine yönelik beklenti kategori ve sıklığındaki bu yüksek oran öğretmen adaylarının beklentileriyle dersin içeriğinin önemli ölçüde örtüştüğünü ifade etmektedir.

Geri bildirim içerikte dördüncü konu olarak ele alınmıştır. Ancak bunun iletişim ögelerinden ayrı değerlendirilmesi yanlış bir durumdur. Çünkü geri bildirim iletişimi süreç hâline getiren unsurdur. Alııının kaynaktan gelen mesaja verdiği tepkiyi ifade etmektedir. Bulgulardaki en ilginç sonuçlardan biri de geri bildirime yöneliktir. Çünkü adaylar geri bildirimle ilgili hiçbir beklenti ifade etmemişlerdir. Kitle iletişim araçlarında bile telefon, e-posta, sosyal medya araçları gibi imkânlarla geri bildirim alma çabasının yaşandığı günümüzde kişilerarası iletişimde geri bildirim konusuna yer vermemek düşünülemez. Hele ki söz konusu eğitim olduğunda geri bildirim almadan amaçlara ulaşmak mümkün değildir.

İçerikte yer alan bir başka konu, etkili dinlemedir. Dinleyerek etkileme, günümüzün yoğun yaşam temposunda ihtiyaç duyulan ve kullanılan başarılı yollardan biridir. Adaylar beklentilerini 1 kategoride 15 sıklıkla dile getirmişlerdir. Bu kategori kaynağın bir özelliği olduğu için orada da değerlendirilmeye alınmıştır. Kategori ve sıklığın azlığına rağmen içerikle örtüşme sağlanmıştır.

Ders içeriğindeki altıncı konu kişilerarası iletişimi engelleyen etkenlerdir. Olumlu ve etkili iletişim amaçlanırken iletişimi olumsuz etkileyen durumların bilinmesi ve bunların ortadan kaldırılması amaca giden süreci kolaylaştıracaktır. Öğretmen adayları bu yöndeki beklentilerini 2 kategoride 24 sıklıkla ifade etmişlerdir. Bu durum içerikle beklentilerin uyuştuğunu ifade etmektedir.

Iletişimi kolaylaştıran etkenler, içerikte yer almasına rağmen öğretmen adaylarının beklenti dile getirmediği konulardandır. Hâlbuki etkili iletişimi amaçlayan bir kaynağın bu beklenti içinde olması gerekmektedir.

Duyguların iletişimde rolü ve kullanılması konusu içerikte yer almaktadır. İnsanı harekete geçiren temel etkenlerin başında gelen (Cialdini, 2001) duyguların etkisi ve iletişimde kullanılması hususunda adaylar beklenti belirtmemişlerdir.

İletişimde çatışma ve önlenmesi, içerikte ayrıca ele alınan konulardan biridir. Çatışma iletişim engellerindendir. İçerikte her iki konuda ayrı ayrı ifade edilmiştir. Öğretmen adayları engellere yönelik beklenti ifade ederken çatışma kavramına ve çatışmanın önlenmesine yönelik ayrıca bir beklenti dile getirmemişlerdir.

Ders içeriği eğitimde iletişim konusunu; öğrenci, öğretmen, veli iletişiminde dikkat edilmesi gereken önemli hususlar şeklinde ifade etmiştir. Katılımcılar beklentileri bu boyutta 10 kategori 313 
sıklıkla dile getirilmiştir. Katılımcıların öğretmen adayı olduğu dikkate alındığında bu yönde beklenti dile getirmeleri olumlu bir durumdur. Bu boyutta da ders içeriği ile aday beklentileri örtüşmektedir.

İçeriğin son konusu iletişim uygulamalarıdır. Ancak ders üç kredilik teorik bir ders olarak kurgulanmıştır. Bu içeriğin kendi içinde çeliştiğini göstermektedir. Öğretmen adayları da dersin işlenişi boyutunda yer alan 3 kategoride 45 sıklıkla derste uygulamalar yapılmasını hatta dersin ölçme ve değerlendirme işleminin uygulamalı olmasını istemektedirler. İletişim bir beceri olduğuna göre verilen iletişim eğitiminin de uygulamalı olması beklenmektedir. Buradan hareketle dersin uygulamalı bir ders olarak tasarlanması yerinde olacaktır.

Ders içeriği ve beklenti-öneri karşılaştırılması sonucunda içerikle beklentilerin 5 konuda örtüştüğü, 6 içeriğe yönelik ise beklenti ve öneri sunulmadığı görülmektedir. Illetişim unsurlarına yönelik beklenti kategori ve sıklığındaki yüksek oran, öğretmen adaylarının beklentileriyle dersin içeriğinin bu boyutta önemli ölçüde örtüştüğünü ifade etmektedir. Öğretmen adayları geri bildirim alma becerilerini geliştirme yönünde beklenti ifade etmemişlerdir. Yüksek düzeyde örtüşmenin ortaya çıktığı bir diğer konu ise eğitimde iletişimdir.

Bu araştırmayla ilgili benzer bir çalışmada, öğretmen adayı ve öğretim elemanlarından sınıf-içi iletişimin anlamlı olması için öğretmenin taşıması gereken nitelikleri önem sırasına göre yazmaları istenmiştir. Öğretim elemanları, sınıf-içi iletişime dayalı olarak öğretmenlerin "alan bilgisine sahip olma, dili açık ve anlaşılır biçimde kullanma, demokratik olma, uygun cümleler kurma, iletişimi destekleyici fiziksel ortamlar oluşturma" gibi özellikleri; öğretmen adayları "güler yüzlü olma, empati becerisine sahip olma, sevgi, beden dilini etkili kullanma, hoşgörülü davranma, iletişime istekli olma, mesleği sevme, öğrenciye saygı duyma, dili etkili kullanma" gibi özellikleri ilk sıralarda belirtmişlerdir. Bu sonuçlara göre öğretmenlerin sahip olması gereken iletişim becerileri konusunda öğretim elemanı ve öğretmen adaylarının algılarının farklı olduğu ve öğretmen adaylarının sınıf-içi akademik/mesleki süreçlerden çok, günlük ya da kişisel iletişim süreçlerinde ağırlık kazanan iletişim becerilerini temele aldıkları söylenebilir (Baykara Pehlivan, 2005). Ders içeriklerini öğretim elamanlarının hazırladığı düşünülürse içerikle öğretmen adayı beklentileri arasında farklılıkların olması bu araştırma verileriyle de desteklenmektedir.

\section{Sonuç ve Öneriler}

Öğretmen adayları, etkili iletişim dersinden beklenti ve derse yönelik önerilerini; 5 boyut, 87 kategori ve 1758 sıklıkta ifade etmişlerdir. Bu bulguların sınıflandırılmasında iletişimin temel ögeleri olan kaynak, mesaj, kodlama, kanal, alıcı ve geri bildirimden yararlanılmıştır. Ardından iletişim engeli, eğitimde iletişim, ders öğretim elemanı ve dersin işlenişine yönelik beklenti ve öneriler verilmiştir. Daha sonra ders içeriği ve beklenti-öneri karşılaştırılması yapılmıştır. Ders içeriği 11 alt konudan oluşmaktadır. İ̧erikle beklentilerin 5 konuda örtüştüğü, 6 konuda hiçbir beklentinin içeriğe uymadığı tespit edilmiştir. 
Ders içeriğinde olmayan ancak öğretmen adaylarının beklenti ve çoğunlukla öneri sunduğu iki boyut daha vardır. Bunlar: Ders öğretim elemanı ve dersin işlenişidir. Buradan adayların içerikte olamasa bile belki de diğer ders tecrübelerinden hareketle, dersten daha yüksek verim almak istedikleri sonucu çıkarılabilir. Bu dersin 2007 yılından itibaren bütün öğretmen yetiştirme programlarında yer aldığı, derse çoğunlukla Türk dili okutmanı kadrosundaki öğretim elamanlarının girdiği ve derse yönelik yetişmiş öğretim elemanı azlığı göz önünde bulundurulursa adayların beklenti ve önerileri öğretim elemanı yetiştiren kurumlarca dikkate alınması gereken bir husustur.

Bu dersin, ikna edici iletişim ve öğretmen adaylarının bunu kullanması şeklinde en az iki döneme yayılarak içeriğinin genişletilmesinin, teorik ve uygulama şeklinde yeniden kredisinin tespit edilmesinin yararlı olacağı düşünülmektedir. Bu noktada görev, Yükseköğretim Kuruluna düşmektedir. Eğitim fakültelerindeki dersler ve derslerin içerikleri belirlenirken, öğretmenlerin bilgi aktarımını ve beceri kazandırma faaliyetlerini dile dayalı etkili iletişimle yapacakları göz önünde bulundurulmalıdır.

Ders içeriğine güncel ve sık kullanılan bir kodlama türü olan görsel kodlama eklenmelidir. Görsel kodlama, ilkokul ve ortaokul Türkçe dersi programlarında bile ele alınan temel konular arasındadır.

Öğretmen adaylarının etkili iletişim dersine yönelik beklenti ve önerilerinin çeşitli değişkenlere göre değişip değiş̧mediği yönünde de araştırmalar yapılması yukarıda sunulan bulguların zenginleştirilmesi açısından uygun olacaktır.

Etkili iletişim dersinin içeriği hususunda öncelikle bu konuda uzman olan ve derse giren tüm öğretim elemanlarının görüşlerinin alınması ders içeriğinin geliştirilmesi sürecine katkı sağlayacaktır.

\section{Kaynakça}

Aspy, D. and F. Roebuck. (1983). Researching person-centered issues in education. Fredoom to learn for the 80's. Rogers, C. R. (ed.). Columbus, Ohio: Charles E. Merrill.

Baykara Pehlivan, K. (2005). Öğretmen adaylarının iletişim becerisi algıları üzerine bir çalışma. ilköğretim-Online. 4(2), 17-23. http://ilkogretim-online.org.tr

Büyüköztürk, Ş., Çakmak Kılıç E., Akgün Erkan Ö., Karadeniz Ş., Demirel F. (2008). Bilimsel Araştırma Yöntemleri. Ankara: PegemA Akademi.

Cialdini, R. B. (2001). Insanları etkileme yolları. (Çev. A. Dönmez). Ankara: İmge Kitabevi.

Cialdini, R. B. (2006). Iknanın psikolojisi. (Çev. F. Yalım). İstanbul: Mediacat Kitapları.

Cüceloğlu, D. (1993). Insan ve davranışı. (Dördüncü Baskı). İstanbul: Remzi Kitabevi.

Çevik, D. B. (2011). Müzik öğretmeni adaylarının iletişim becerileri, Gazi Eğitim Fakültesi Dergisi. 31 (1), 1-13.

Çuhadar C., Özgür H. ve Akgün F., Gündüz ş. (2014). Öğretmen Adaylarının İletişim Becerileri ve illetişimci Biçimleri. Ahi Evran Üniversitesi Kırşehir Eğitim Fakültesi Dergisi (KEFAD) 15(1), 295-311.

Deniz, K. (2007). Illköğretim ikinci kademede konuşma ve dinleme yoluyla öğrencileri ikna üzerine bir araştırma. Gazi Üniversitesi, Eğitim Bilimleri Enstitüsü, Türkçe Eğitimi Ana Bilim Dalı. Yayımlanmamış Doktora Tezi.

Deniz, K. (2013). Eğitimde etkili iletişim. A. Güzel, H. Karatay (Ed.). Türkçe öğretimi el kitabı. (s. 521-570). Ankara: Pegem Akademi. 
Deniz, K. (2015). Türkçe öğretmeni mi iletişim eğitmeni mi?. D. Uçgun, A. Balcı (Ed.). Akademik hayatının 25. yılında Türkçe eğitimi alanının ilk profesörü Murat Özbay'a armağan. (s. 449-462). Ankara: Pegem Akademi.

Evliyaoğlu, G. (1987). Iletişim psikolojisi psikolojik iletişim. Ankara: Gazeteciler Cemiyeti Yayınları.

Gürüz D., Temel Eğinli A. (2013). Iletişim becerileri. Ankara: Nobel Yayınları.

Gordon, T. (1998). Etkili öğretmenlik eğitimi (Dördüncü Baskı). (Çev. E. Aksay). İstanbul: Sistem Yayıncılık.

Gordon, T. (2001). Çocukta dış disiplin mi iç disiplin mi? (ikinci Baskı). (Çev. E. Aksay). İstanbul: Sistem Yayıncılık.

Güven ve Yalçınkaya Akyüz (2001). Öğretmen Adaylarının Illetişim ve Problem Çözme Becerilerine illişkin Görüşleri. Ege Eğitim Dergisi. 2001 1(1), 13-22.

Hale, R., Whitlam P. (1997). Insanları etkileme gücü. (Birinci Baskı). (Çev. T. Topuzoğlu). İstanbul: Epsilon Yayıncılık.

Hogan, K. (2007). Başkalarını sizin gibi düşürmeye nasıl ikna edersiniz? Ikna etmenin psikolojisi. (Birinci baskı). (Çev. T. S. Güneş), E. Karanimoğlu. İstanbul: Yakamoz Yayınları.

Hogan, K., SPEAKMAN J. (2007). Gizli ikna taktikleri. (Birinci baskı).(Çev. T. Gezer). İstanbul: Yakamoz Yayınları.

İmre, Ü. (2000). Sınıf öğretmenlerinin iletişimsel etkililikleri. Ankara Üniversitesi, Sosyal Bilimler Enstitüsü, Eğitim Programları ve Öğretim Ana Bilim Dalı. Yayımlanmamış Yüksek Lisans Tezi.

Kağıtçıbaşı, Ç. (2005). Yeni insan ve insanlar. (10. Baskı). İstanbul: Evrim Yayınevi.

Karadoğan, E. (2003). Kişiler arası iletişim sürecinde güven unsuru, güven ve ikna ölçeği örneği. İstanbul Üniversitesi, Sosyal Bilimler Enstitüsü, Halkla İlişkiler Ana Bilim Dalı. Yayımlanmamış Doktora Tezi.

Köknel, Ö. (1997). Insanı anlamak. (Altıncı Baskı). İstanbul: Altın Kitaplar Yayınları.

Muallimoğlu, N. (2005). Bütün yönleriyle hitabet. (Yedinci Baskı). İstanbul: Avcıol Basım Yayın.

Mcquail, D. and Wiahl, S. (1993). Iletişim modelleri. (Çev. M. Küçükkurt). Ankara: İmaj Yayınları.

Norton, R. W. (1983). Communicator style: theory, applications, and measures. Beverly Hills, CA: Sage.

Özçınar, Z. (2003). Öğretmen-öğrenci-veli iletişimsel yeterlilikleri ve öğrenci başarısıyla olan ilişkisi. Ankara Üniversitesi, Eğitim Bilimleri Enstitüsü, Eğitim Programları ve Öğretim Ana Bilim Dalı. Yayımlanmamış Doktora Tezi.

Rocha, R. (01.12. 2003). 15 ways to influence and persuade anyone.<http://www.askmen.com/ moneysuccessful_100/104_succes.html> (Erişim tarihi: 01.12. 2003).

Tutar, H., Yılmaz, M. K. (2003). Genel iletişim. (Üçüncü Baskı). Ankara: Nobel Yayınları.

Uzuntaş, A. (2013). Etkili iletişim: anlatabilmek ve anlayabilmek. Kastamonu Eğitim Dergisi. 21(1), 11-30.

Yarar Kaptan, S. ve Oğuz, A. (2011). Etkili iletişim dersinin sınıf öğretmeni adaylarının iletişim becerilerine etkisi. 20.Ulusal Eğitim Bilimleri Kurultayı. 8-10 Eylül 2011. Burdur.

Yıldırım, A. ve Şimşek, H. (2013). Sosyal bilimlerde nitel araştırma yöntemleri. Ankara: Seçkin Yayınları.

YÖK. (2015). Türkçe öğretmenliği lisans programı.http://www.yok.gov.tr/documents/10279/49665/ turkce_ogretmenligi.pdf/d0d11c2d-bc83-4186-8717-b33597eb8eb6 (Erişim tarihi: 19 Mart 2015). 